\title{
Semiotic Analysis of Petroglyph «Ancient Turks and the Mother Goddess Umay/Umai»
}

\author{
Tatiev E.E. ${ }^{1}$, Yesim G. ${ }^{2}$, Sarkulova M.S. ${ }^{3}$, Mukataeva A. A. ${ }^{4}$ \& Tatieva M. E. ${ }^{5}$ \\ ${ }^{1}$ Doctoral student at the Eurasian National University named after L. N. Gumilyov, St. Satpayev 2, Nur- \\ Sultan, 010008, Republic of Kazakhstan E-mail: ertisuly82@mail.ru https://orcid.org/0000-0001-6368-1251 \\ ${ }^{2}$ Doctor of Philosophy, Professor of the Eurasian National University named after L. N. Gumilyov, St. \\ Satpayev 2, Nur-Sultan, 010008, Republic of Kazakhstan Email: garifollaesim@mail.ru \\ https://orcid.org/0000-0003-4001-9235 \\ ${ }^{3}$ Candidate of Philosophical Sciences, Associate Professor of the Eurasian National University. L. N. \\ Gumilyov, St. Satpayev 2, Nur-Sultan, 010008, Republic of Kazakhstan Email: manifa.s@mail.ru \\ https://orcid.org/0000-0002-5992-2814 \\ ${ }^{4}$ Candidate of Philosophical Sciences, Associate Professor of the "Shakarim Semey University", St. Glinka, \\ 20 "a", Semey, 071412, Republic of Kazakhstan Email: aizat720804@mail.ru https://orcid.org/0000-0001- \\ 9046-9256 \\ ${ }^{5}$ Master of the "ShakarimSemey University", st. Glinka, 20 "a", Semey, 071412, Republic of Kazakhstan \\ Email: tatieva_me@mail.ru https://orcid.org/0000-0003-2365-8123
}

\begin{abstract}
The study of historical artifacts from a scientific point of view is acknowledged in the literature. A clear understanding of our historical roots is connected with the study of cultural heritage from empirical and especially quantitative bases of research already done by scholars like Rudenko (1927) and Gavrilova (1965). Yet, another important method of studying historical material objects is semiotic analysis, which allow studying prehistorical visual culture artifacts as a system of signs, which may be deciphered, and related to deducible meaning and sense in the context of ethnographic, cultural and specifically semiotic references which bear on location, identification and understanding of such material. Our research in this article is dedicated to a study of certain visual material artifacts from the geographical region of the Eastern Altai. In particular, we study petroglyphs on a boulder that was discovered during the excavations of the Kudyrge burial ground near the Chulyshman River, which according to some sources belong to the Turkic culture of the early period, and have recently begun to arouse the interest of scientists. Various empirical methods have been used to explore the stone monument (statue) called "Kudyrginsky plot". Some of the techniques as those of pioneering research scholars like Rudenko and Gavrilova, include archaeological, historical, historical-chronological, historical-comparativemethods, as well as approaches including analysis and synthesis of the obtained data. In turn we supplement the existing methodological approaches with a semiotic-ethnographic analysis of the information available on the "Kudyrginsky plot". We argue that semiotic analysis of ancient artifacts, following methods established by Reday (2019) and Martel (2020), can offer adequate information for the understanding of a rich historical heritage sight like the Kudyrginskyplot.
\end{abstract}

Keywords: Altai, Central Asia, Petroglyph, Semiotics, Tengri, Visual Artifact Augmentation 


\section{Introduction}

Advanced aesthetically significant discoveries have been made by application of scientific methods in understanding artifacts. Modern day computers, and special digital devices have been employed to quantify cultural properties of objects from specific historical time periods [Little, 2016, 135-152; Reich, 2008, 799-806; Krenke 2019, 110-116; Brown, 2014, 7]. Following this general technique of scientific analyses we shall enumerate how they have contributed to the illumination of a rock art stone monument called the Kudyrginsky plot. Our first sections are dedicated precisely to a review of scientific methods already used for a comprehensive reconstruction of this rock art site from the Eastern Altai.

In the second section of our article, we conduct a semiotic analysis of this rock art compendium to supplement cultural information for the site and the artifacts. We have also involved application of special technical devices and methods to make semiotic inferences from the objects. We propose that semiotic analysis of artifacts, especially those without immediately available tangible or cultural ethnographic references, may be conducted for any artwork by looking at the object with technological extensions and inferring possible facts about its existence and its references in a world of indexical representation of objects on visual planes or surfaces. Such methodology has been approved in the research of Renfrew (2004) and Martel (2020).

However, it is important to realize that we have taken the aid of computer graphics to extend the visual implications of the image that was considered for our project. The rock art that is visible in the Kyudirgynsky plot was augmented three dimensionally to examine what the mental effect of that image might have meant in all its potential ramifications in space. This way we have been able to foreground the content of our references to the object. Semiotic analysis was thus applied once the object, available in crude form in the Eastern Altai, was digitally enhanced to answer basic questions of its representational functions and its indexicality.

Our method is thus perhaps more appropriately considered as a report of an experiment combining scientific and humanistic semiotic approaches. For clarity, we would like to note that we used the word "experiment" in our research not for the purpose of identifying hypotheses and theories or arguments, but as an example of semiotic science in which we used various tools and techniques for the study of the said petroglyph and to consider whether such means could lead to a definitive interpretive summary of the object in question. A major purpose of the experiment was to study the feasibility and results of using a number of methods and techniques (multidisciplines). Only as such does the article note that in the semiotic analysis of petroglyphs, the "experiment" was carried out on the basis of certain assumptions about the artistic or semantic status of an abject from a historical past.

\section{Stone Boulder Grave No. 16: Basic Research on a Visual Artifact}

Hence the example of a material picture like "Ancient Turks and the mother goddess Umay /Umai/", which is considered for our study. The petroglyphs carved on stone that are subsumed in our title Ancient Turks and the Goddess Umai were first discovered by Soviet scientists [Rudenko, 1927, 37-52]. These petroglyphs were discovered in 1924-25 by the Altai expedition of the Ethnographic Department of the Russian Museum under the leadership of S. I. Rudenko and 
A. N. Glukhov who were studying the Kudyrge Mole burial ground near the Chulyshman River, which is part of the territory of the Ulagan district and is currently located in the Russian Federation, namely in the Altai Republic [Rudenko, 1927,38]. The Soviet scientists' discovery of petroglyphs "Ancient Turks and the mother goddess Umay/Umai/" were also studied for the first time by Rudenko $(1927,37-52)$ and then Gavrilova $(1965,145)$. This petroglyph complex was considered to be canonical for the meaning of the historically evolved goddess identity of "Umai" [Kotov, 2010, 111-114; Kubarev, 2017, 93-103; Zhernosenko, 2016, 312-317].

In Soviet times, petroglyphs were studied by specialist archaeologists. Opinions on the analysis of petroglyphs differ [Azbelev, 2010. 5,17,23; Khudyakov, 2010, 97]. Nevertheless, there is a consensus regarding the central character of the petroglyphic painting "Mother Umai /u mei/". This is evidenced by the drawing with intermittent red lines in the center of Fig. 1.

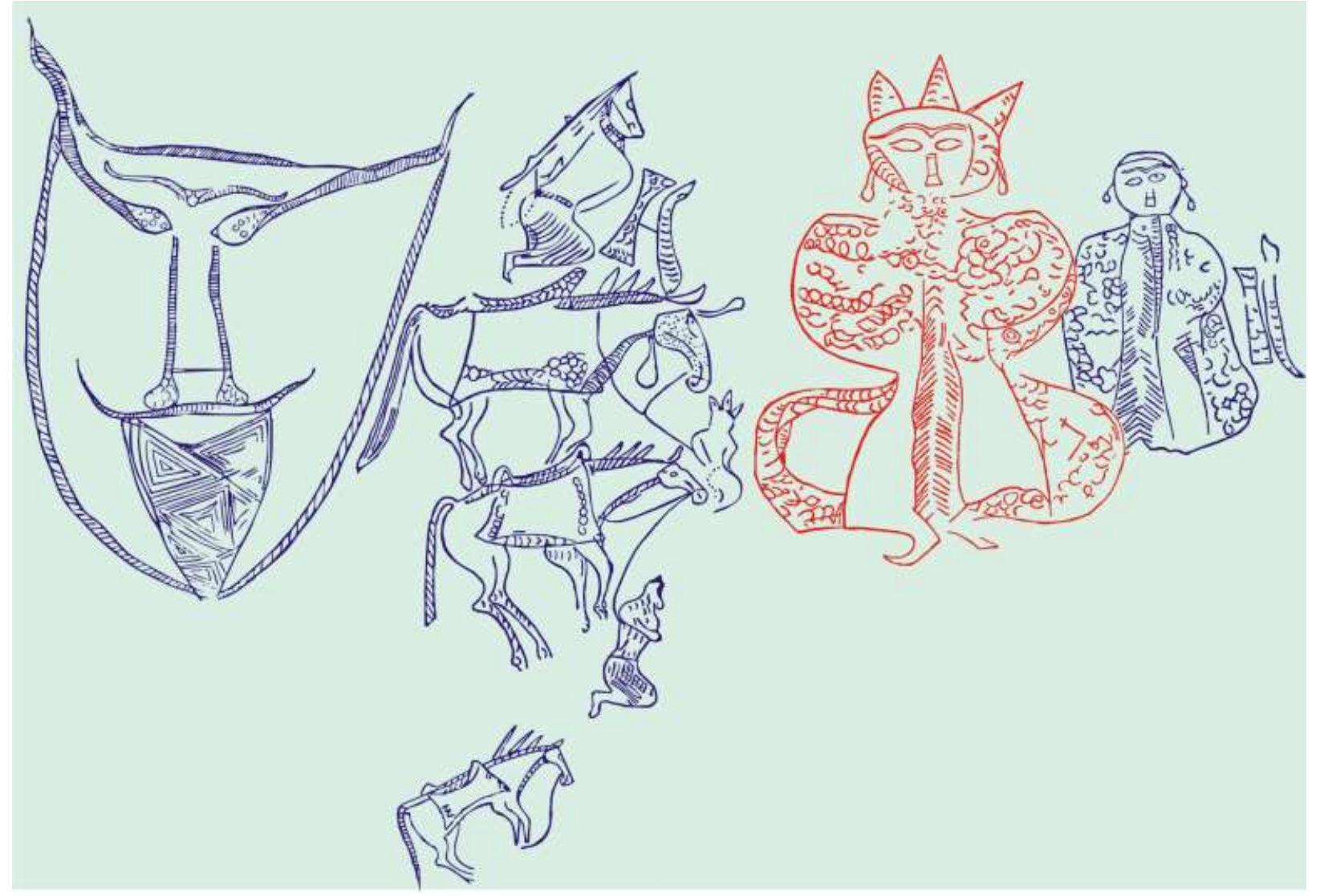

Figure 1: Mother Umai /Umay/

The common "Umai / Umay/" or "mother goddess Umai" motif, that is visible here in the configuration of the red lines, is the name of a female God in ancient Turkic-Mongolian mythology and Tengirism [Cotterell, 1999, 417]. She is represented in science as a mythical mother goddess, continuing to effecther manifestations in the Turkic and Mongolian cultural traditions. There are also claims that mother goddess Umai is similar to the Earth mother gods in other world cults [Edwards, 2013, (3)]. 


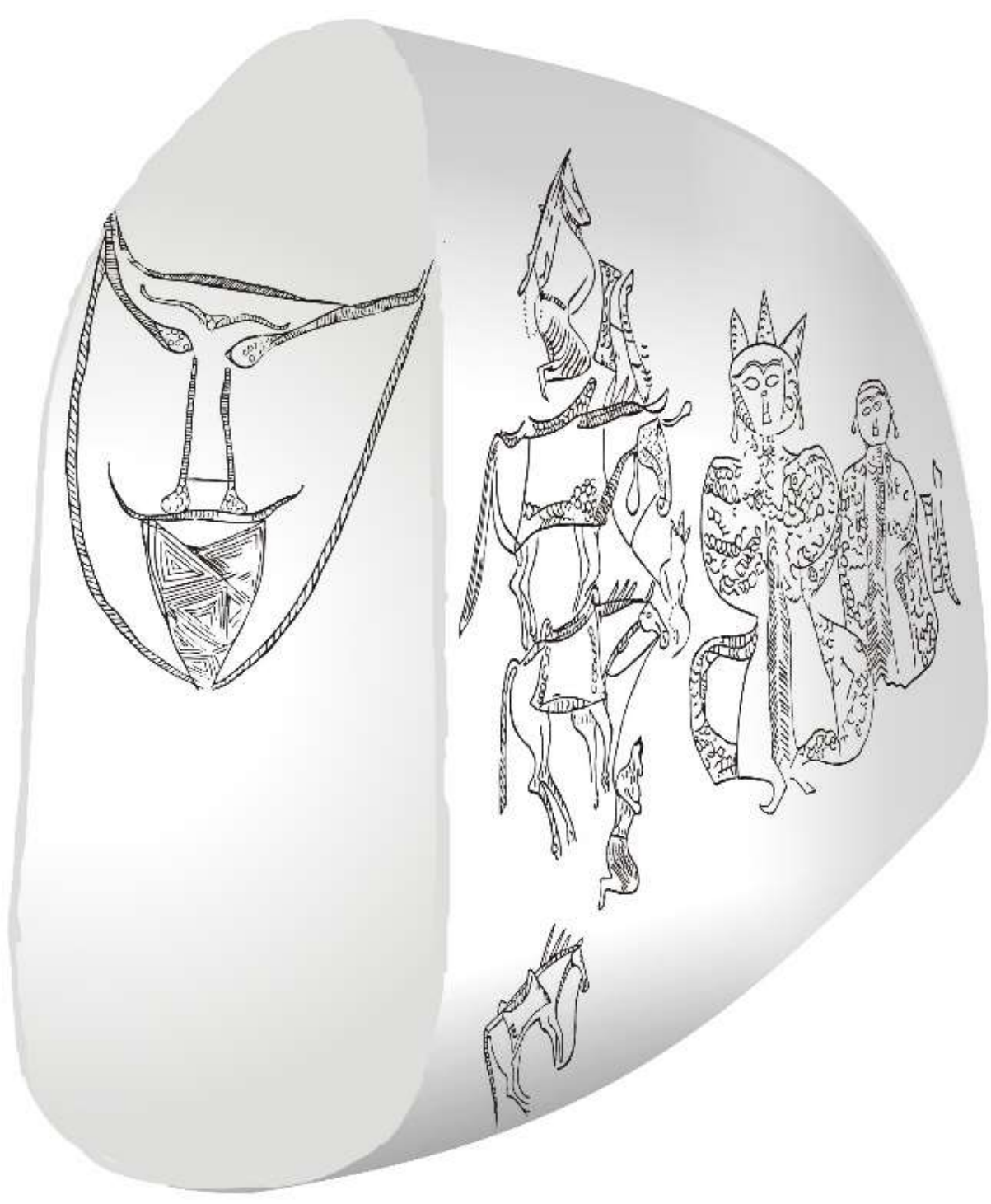

Figure 2: Technical Reconstruction

The original petroglyph that was found in the tomb necropolis No. 16 in Kudyrga does not survive. There is only an existing engraving of the print made by S. I. Rudenko and A. N. Glukhov [Rudenko, 1927, 51]. The print features the goddess Umai, people /ancient Turks/ and also another picture. In addition to these pictures from the plane on the face of the stone-boulder, we see otherrelated images. We developed a technical reconstruction of the image with computer programming and thus this supplementsthe absence of original image (Fig. 2).

The petroglyph shows two people in a robe, three people on their knees, a person's mask in a separate plane, horses, and two attributes (Fig. 2). 


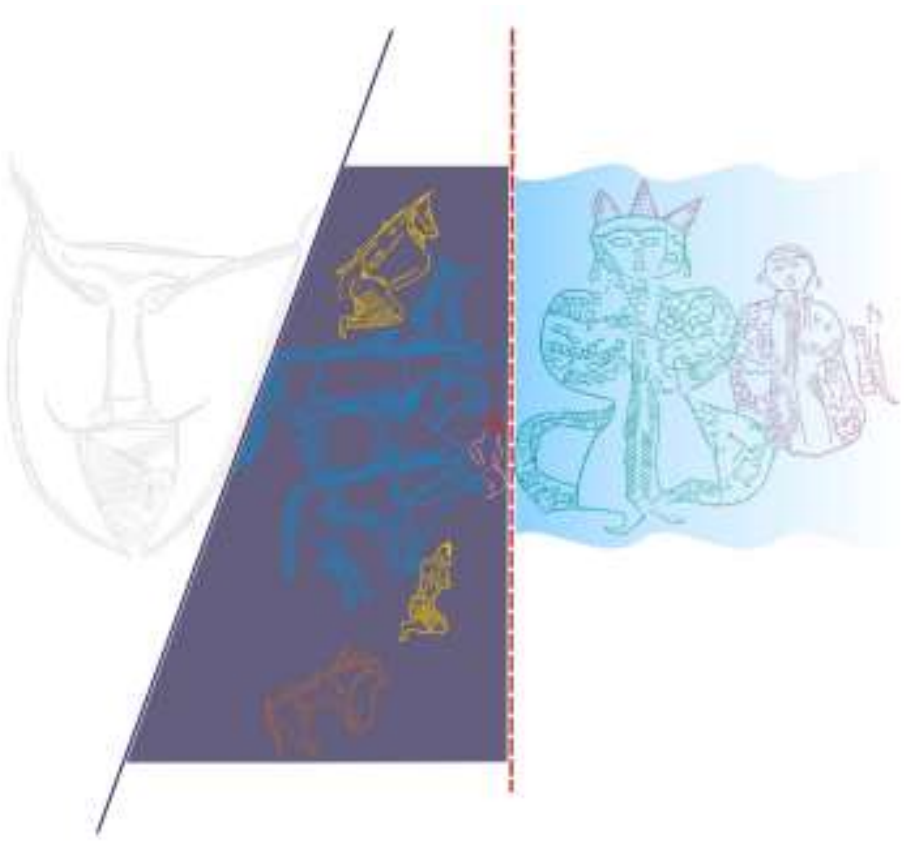

Figure 3: Human ritual sacrifice

Soviet scientists who studied this petroglyph put forward the hypothesis that the painting has a ritual significance, since the boulder stone on which it is depicted was discovered inside a cemetery [Rudenko 1927, 51-52; Gavrilova, 1965, 18-19]. Given this assumption, we get the idea that shamans or a scene of shamans performing the same rite is depicted here. Visual evidences from a number of petroglyph suggest resence of following details:

1. The attribute of a person sitting on knees is on the vertically upper segment and the person wearing the chapan behind the image, which is recognized as "mother Umai", carry an attribute similar to one another (extreme right Fig. 3). Researchers consider them as "bows and arrows of war armor". We believe rather that both items look like shamans, notwarriors or associated weapons. The two attributes are dedicated to shamans possessions or associations: such as "tambourine and mallet". But the tambourine should have been ideally depicted as round.

2. Drawn on a separate side-sketch of a man is the "mask-larva". This is the shaman's headdress. The sketch of this man is similar to the details of "mother Umai" and the faces in the image behind her, eyebrows, eyes, nose. So Umai and his companion next to him (including the green masks) are definitively masked dancing shamans.

3. The outfits of the two figures dressed in chapan are very similar to each other. Similarities can be traced in the rainbow patterns and linear stripes on the chapan. In addition to the fact both images have windy earrings, and it all looks a shaman's headdress.

4. We can see that the kneeling people are on the upper part of the image and have the shape of a head. They deviate from the anatomical base and wear a triangular-shaped mask. 
Given these arguments, we can say that the picture depicts shamans, but the image on the stone-boulder was built several thousand centuries ago. If we must present circumstantial evidence, we have to find them in modern contemporary ethnographic evidences of shamanic traditions and clothing.

\section{Matching Graphs: Visual Augmentation of Artifact}

Basically, the shaman's headdress is associated with animals and birds. They are made of horned animals, bird feathers and the skins of carnivorous animals [Mikhailova, 2018, 5-26]. Shamans also wear a mask-disguise when performing the ritual. Studies of shamanic masks of Siberian peoples, such as the masks of P. E. Zabolotskaya, allow us to identify some key types [Zabolotskaya, 2011, 24-35]. Using the corresponding graph (Fig. 4), we placed four symbols in separate cells, which were very similar in function to the image of the "shaman" in the petroglyph. Conclusions by analogy with the masks of modern shamans, which correspond to these images on the petroglyph, were used to develop this table. Shamanic masks of the third column were not included in the cells. They are closely related to the ethnography of the activities that many people have been doing lately. Masks In the Cells of the third row are facial, which are used to represent the performative function of "procreation". For example, the shaman's mask, the third cell from the top in the list, is that of "kOcho", or "kOcho-kan" [Nazarov, 2016, 110], which is used in ritual acts of the steppes of the South Siberian region under the name "attractiveness of fertility" [Zabolotskaya, 2011, 31]. This tradition existed among the ancient tribes of Cumans, Shors, Chelkans, etc.

The next mask type "Hura hora bed" nganasan in the second cell of the third column was used in the act of "divine dance" [Zabolotskaya, 2011, 26]. The mask is similar to the shaman's mask in the third cell of the first column. The shape of the mask is similar. Secondly, the mask of "Hua Horakoika" is called among Ganganasans the "dance of the gods": perhaps that is why researchers of petroglyphs perceive the image of a man in the center of the image as "god" (Diosegi, 1955, 97; Alekseev, 1984, 151). 


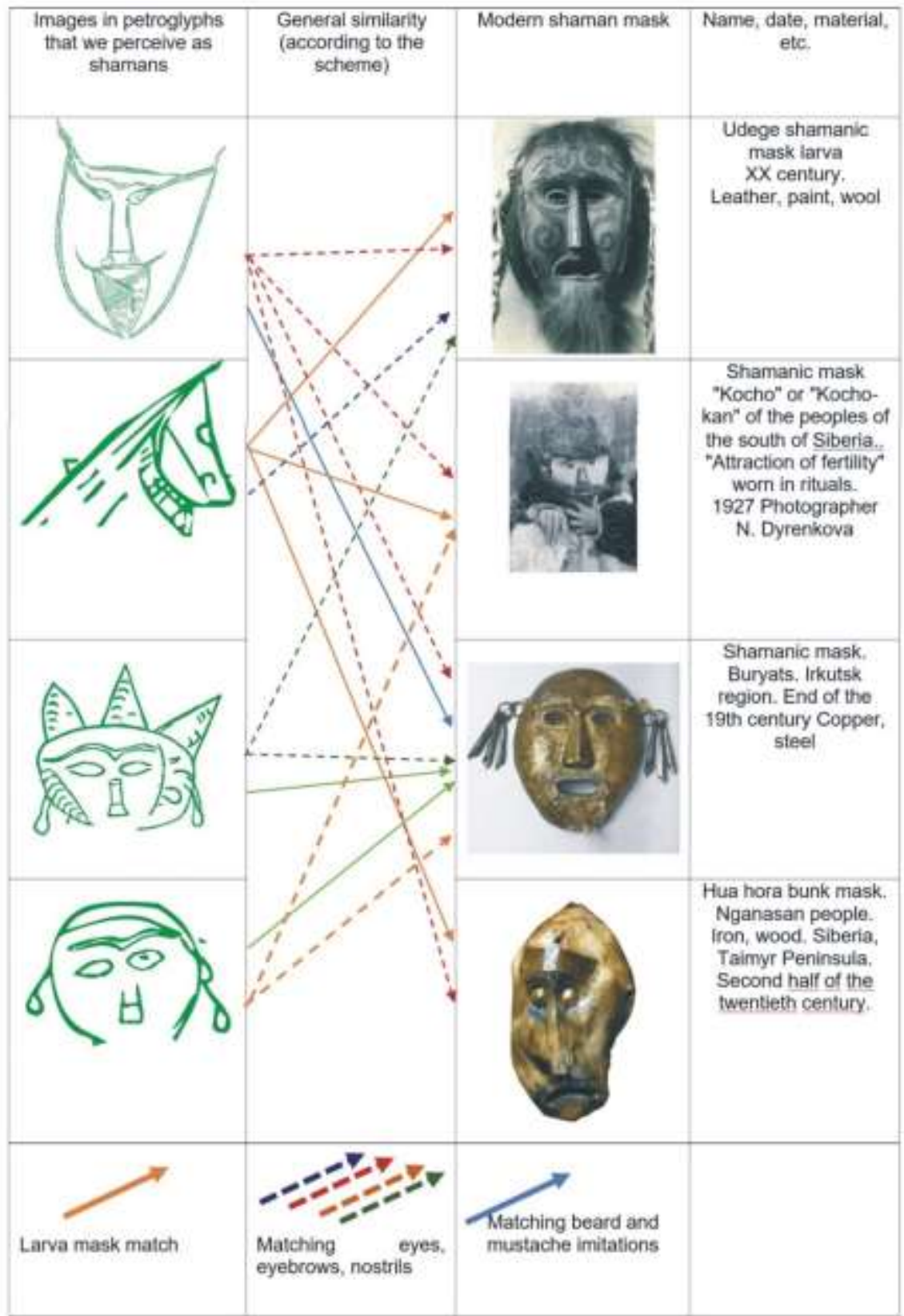

Figure 4: Complian cefeatures

The Udegelarva mask is slightly closer to the image in the second cell of the first column. The beard-mustache and eyebrows stand out especially. Shaman and shamanic ritual are directly related to the religion of shamanism. Shamanism is an ancient belief consisting of a religious practice performed by a shaman. The ancient Turks and Mongols worshipped Tengirism and practiced shamanism [Place, 2008, 11]. Today, this phenomenon has been preserved among the Siberian peoples. 
The shaman is is also the successor of the healing tradition. The shaman performed the ritual in the form of ecstasy, trance and communication with spirits. It Is worth noting that the shamanic tradition exists in the traditions of faith around the world. The shaman adheres to the magicoreligious practice without changing his basic set of actions, although he has different names. For example, among the Korean people, Mudan (i.e. shaman) "Hwangedo nerim kut" represents shamanic initiation; it is customary to say that the North American Indian "adanti" falls into a trance typical of a shamanic ritual. Thus, there is no difference in how the Yakuts call the shaman "oyuun", and the Kazakh calls a "shaman", as one of them calls for "beating the Galley with a kolatushka". Shamans' special clothing is equipped with various items and devices. The main attributes of the Shaman: (a) chapan: chapan with a pattern, chapan with fringe, fur chapans; headdress: (b) mask-disguise, roe deer, deer antlers, scalps of predatory animals, bird wings headdresses; attributes: (c) tambourine; kolatushka, amulets, paints, etc.

In conclusion of these two previous small and short sections, we could say that the distinctive features of petroglyphs are thus listed and determined in order of their importance. Berger examines the distinctive features of the drawings and offers an interpretive analysis [Berger, 2005, 288]. We follow Berger's recommendations regarding the appearance of human-like figures as distinctive features that are visible on the petroglyph.

\section{Photography and Cameratic Interpretive Systems}

Analysis of semiotic elements in photography is closely associated with the name of the French philosopher R. Barthes [Barthes, 2003, 512]. The theory of photography includes composition, concept, idea, perception, principles of thinking, frame, perception, etc. but also consists of analysis of discourse, although here we are primarily looking at the petroglyph as a photograph. What happens if we apply these cameratic experiences of images to an analysis of the petroglyphs under inquiry here? We performed a computational analysis of the human images on the petroglyph. We found and compiled a special list of facial symbols for shamans who performed magical and religious rituals expressing shamanic practices

\section{Composition}

According to archaeological sources this petroglyph is already known to belong to burial grounds. In the center of the image, which leads to a very complex motif with aura, is an image with three heads, all in the form of the goddess Umai. That they refer to the goddess Umai and none other are evident from two counts: first, three people on their knees bow their heads before Mother Umai; the second is an image of a person in a shapan placed on the back of Umai-ana.

Secondly, what is very important is that the petroglyph was drawn by an unknown artist in accordance with the laws of perspective. Usually, petroglyphs on a stone are located at the same level of the plane. Perspective is not preservedin the picture yet the image reveals that the artist looks like a person who knew about perspective. However, the unknown artist did not use the perspective on the other side of the petroglyph, yet this was indeed needed. Horses and kneeling people are represented without any perspective; only the warrior horse below is projected with the opposite perspective. This is an ancient visual reality! But very rarely, a figure in chapan is 
subordinate to perspective. That is what is so surprising within the community of petroglyphic images (fig. 5).

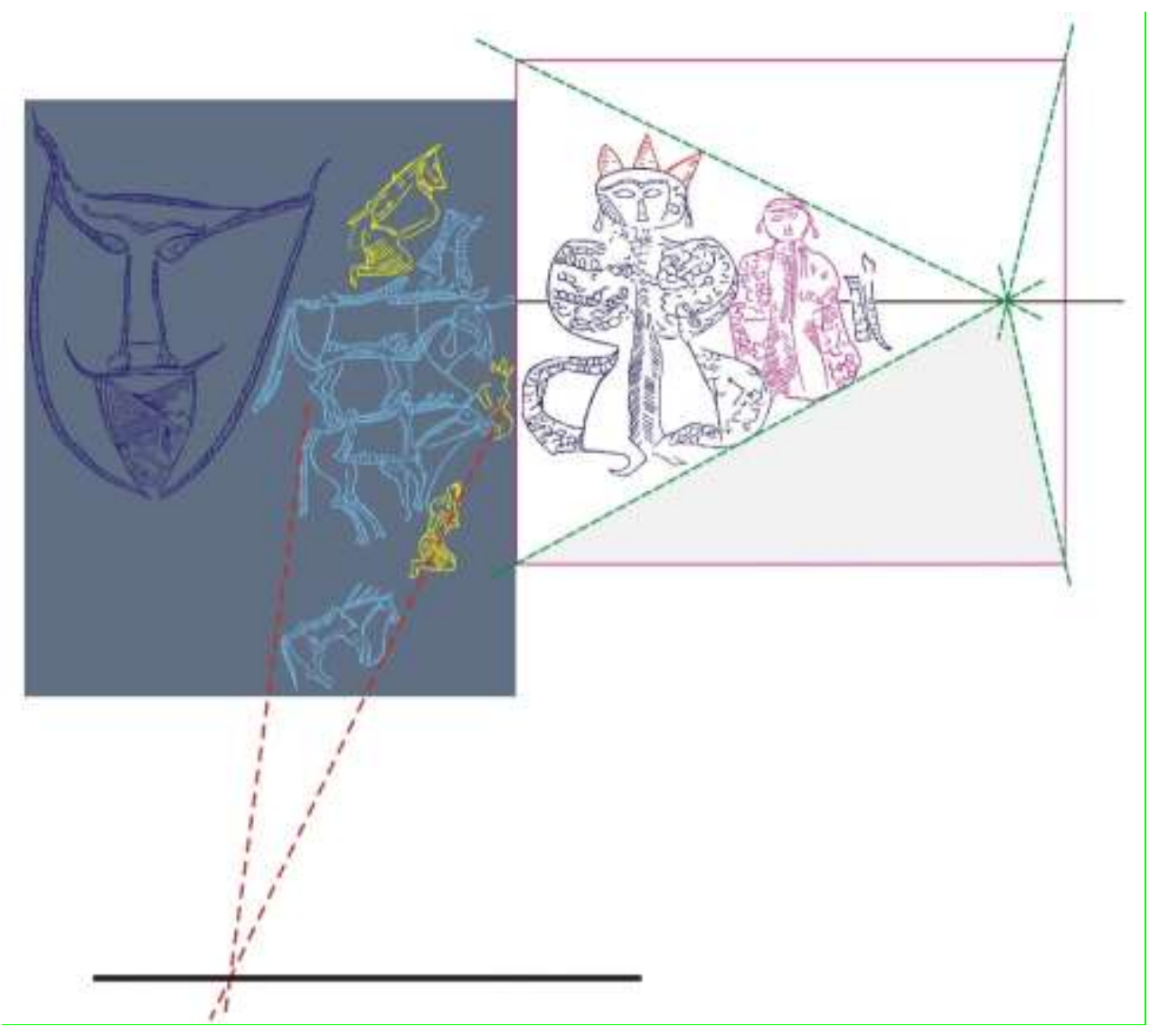

Figure 5: Composition

Research identifiesthe subjects of such petroglyphs as "ancient Turks", so they attribute this petroglyph to the Turkic culture. This can be clearly seen in the picture. Thomson, a Danish scientist who first read the Orkhon-Yenisei runic inscription, proved that the word Umai occurs in the inscription on the pictogram. Orkhon-Yenisei runic inscriptions are monuments of Turkic culture. The second evidence shows that the petroglyphs on the horses studied by us have features of the Turkic culture on the horse harness, especially in relation to the bridle, neck and chain of a horse. Based on these data, the god Umai and the Turks are considered to be the center of the composition. And we see the image of horses with equestrian equipment on artifacts found in archaeological works [Retz, 2004; Stepanova, 2013].

\section{Multiplicity of shots}

If we consider the frame as a simultaneous photographic shooting of different but related figures, then the petroglyph does not correspond to the frame setting. Because petroglyphs dominate the plot, but the shot does not do so. In our opinion, if the stone boulder is intended for people completely buried in the tomb, then the image of a man's face on a separate side of the 
petroglyph, and people kneeling and the goddess Umai herself and the clothes behind her are like separate frames. We have at least three or four frames in the plot. The first image of a male face is considered, i.e. mask of a larva, the second image of kneeling people and horses, the third image of the goddess Umai and the mantle are here placed as individual pictures in a narrative like a tapestry. As a result, the petroglyph is closer to a narrative with a plot rather than to a static frame. Moreover, this is precisely why Soviet scientists called this entire panel of the petroglyph the "Kuderge's plot" - as in drama [Azbelev, 2010, 60].

\section{Effect after perception}

Usually, the image's perception is described only from the perspective of one person or from the perspective of specialists. We made changes and did the following experiment. We prepared special respondents and conducted a survey: "What is your impression of the painting (petroglyph)?" A total of 30 people took part in the survey. The result was not what we expected. It is interesting that some painted through education, others through direct impressions from the picture. Therefore, according to the results of the survey, we prepared a special table called "Knowledge and Impressions from the Picture". We also divided them into four groups according to the table below (Table 1).

Table 1. Survey «What is your impression of the painting /petroglyphs/?»

\begin{tabular}{|c|c|c|c|}
\hline $\begin{array}{l}\text { Group } 1 \\
\text { The } \\
\text { responders } \\
\text { never } \\
\text { encountered } \\
\text { the picture }\end{array}$ & $\begin{array}{l}\text { Group } 2 \\
\text { The respondents } \\
\text { presented their } \\
\text { impressions as } \\
\text { knowledge }\end{array}$ & $\begin{array}{l}3 \text { топ } \\
\text { The responders never } \\
\text { encountered the picture } \\
\text { and described the } \\
\text { experience as secondary } \\
\text { education }\end{array}$ & $\begin{array}{l}4 \text { топ } \\
\text { Responders, } \\
\text { perceiving the } \\
\text { picture with their } \\
\text { thoughts, and not } \\
\text { as knowledge }\end{array}$ \\
\hline 8 & 6 & 5 & 11 \\
\hline
\end{tabular}

According to the results of the respondents, the first group who knows the details of the petroglyph we are studying, in particular, the history of the god Umai and the ancient Turks / 27\% /. The second group, who do not know the plot of the petroglyph, but described the effect of the painting as knowledge (17\%). The third group, who never saw the picture and described their experience as secondary education / 20\% /. The fourth group of respondents answered having perceived the picture not as knowledge, but as their thoughts / 36\% / (Fig. 1).

\section{Answers from selected respondents:}

The first respondent said: "Our ancestors worshiped the God of Heaven, Mother Umai, the sun and the earth. Among them, the worship of Mother Umai has been mentioned since ancient times. Goddess Umai protects the family just as a mother protects the child born from her. The goddess Umai's image is depicted on the stones as a symbol. One of them is a petroglyph in this historic settlement. In this picture behind the goddess Umai is depicted her son or successor, that is, a 
generation. And people who come to worship before Mother Umai ask Umai for her kindness and care. Probably it's the moment of sacrifice. I think "mother Umai takes care of the creation of humanity". Isain (respondent).

The second respondent said: "I have not seen this photo. There are images of ancient horsemen. They come to the holy place in the form of a woman to worship". Toigan (respondent).

A third respondent said: "My impression of photography is that I see it for the first time. I think in this photo people worship Umai, and Umai is worshiped by women when they are pregnant. Goddess Umai is the goddess of women. I think that people bowed to the goddess Umai, who were kneeling in front of the monument. " Inju (respondent).

Fourth respondent: "The ancients came to the goddess and asked her to make a just decision." Tolenya (respondent).

Photography in itself is mute testimony. However, thanks to semiotic analysis, we used photography as a way to approach people's ethnological responses to petroglyphs.

\section{Human Sacrifice}

The next study conducted on the petroglyph "Ancient Turks and Umai" was also an application of the same complex semiotic analysis. We are talking about "scientific hypotheses" of archaeologists who studied these petroglyphs. Kudergi's cemetery was investigated in the first part of the survey.

A.A. Gavrilova suggested first: "The first cemetery was discovered and researched by S.I. Rudenko. Members of Glukhovs' expedition referred to the fact that a child was buried in grave №16. According to A.L. Kyzylasova, the cemetery researcher A.A. Gavrilova suggested that "there was buried an adult, not a baby" [Gavrilova, 1965, 18]. Accepting the statement, it is possible that those praying on petroglyphs sacrificed a man in front of two horses and a three-headed supernatural figure sitting under the knees of Mother Umai. If this is true, then the three-headed image on the roof of the goddess Umai shows that it is unique for a woman, then it turns out to be a buried "girl". We may thus look at the petroglyph from a different angle. In terms of a narrative "plot" the elements may be subdivided and summed up as follows:

\section{Act first}

Kneeling people worship two images and sit down opposite them. As an unknown artist, he clearly shows the border between the people he worships and the gods. In other words, he wanted to convey a sacrificial image, depicting people and gods, people in two poses, and depicting the gods against them.

\section{Act second}

Two kneeling people are depicted in a line behind the gods. The warrior sitting below is depicted above a kneeling shaman or a woman. But none of them seem to have been sacrificed. Because the kneeling shaman, the woman and the warrior look at the gods from the side, and the man in the three-headed image looks at the gods. This means that this image is the center of the petroglyph. 


\section{Act third}

The three-headed image in the middle is a person for sacrifice. Because his arms are bent back and tied to the horse behind it with a rope, and the warrior's arm is tied to the horse with a rope. As if he was holding a rope and begging. The three-headed image in the center of the image shows both hands as evidence that they are looking at the gods. There is a consensus regarding the fact that in ancient times human sacrifice was used to please and pacify the gods [Harner, 2009, 128]. Historical records show that human sacrifice was a religious ritual in earlier world religions, including child sacrifice. It is often found in burial rites of ancient Turkic and Mongol peoples [Rudenko 1927, 40]. Considering the boulder found in the cemetery and the child buried on it, the image in the picture may be said to be representing an episode of a child sacrifice.

\section{A Three-Digit Trinity}

The presence of a triad is one of the most important elements in the scheme of interpretation. The symbol of the Umayyad goddess on the petroglyph "Ancient Turks and Umai" has been traditionally accepted by scholars who study these three iconic images as a "conventional symbol" of Umai Ana and regularly refer to this identity from a scientific point of view. The first aspect of this question refers to what might be the secret of the three-comb formation: category of hat (with a comb-like hairstyle) or head or crown-like configuration? We know that this symbol was used by ancient artists and sculptors to depict women. Later the same symbol became associated with the moon and the sun, the creator of the earth and the mountain, and so on, all associated with standard mythological story. This is clear. But the question is, why is it revealed in the form of triplet?

In our opinion, it is better to look at mother Umai as a whole, rather than as a sum of three headings. Then its semiotic aspect is revealed more clearly. With this in mind, we recommend the following combination.

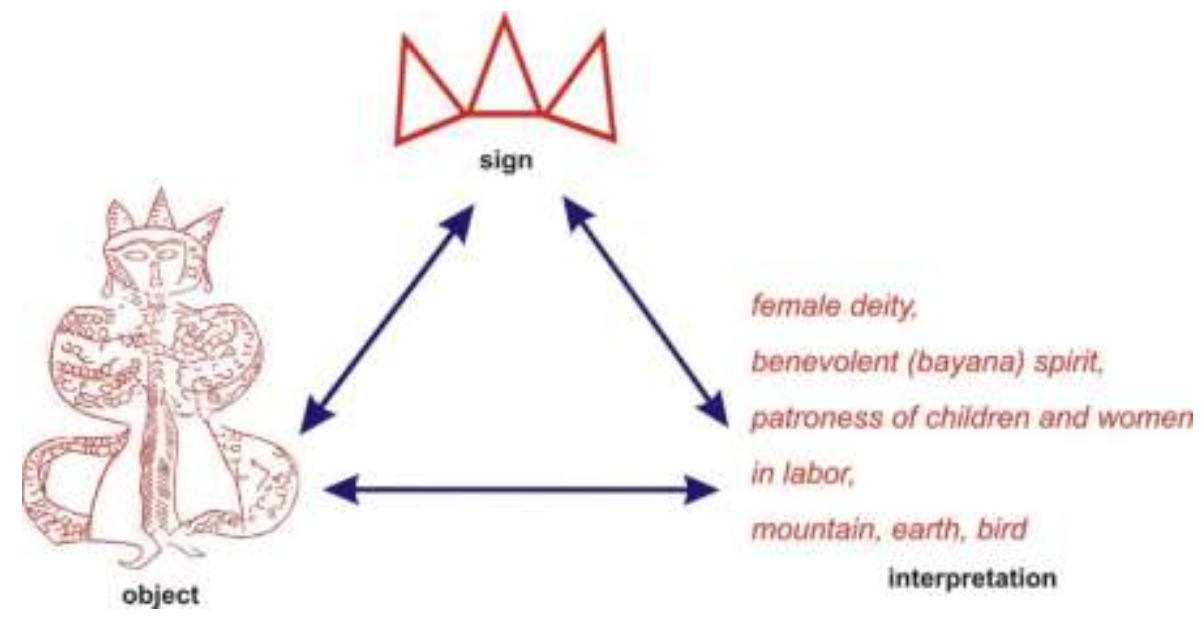

Figure 6: The process of semiosis in the Umai triad

The goddess Umai's image has been preserved in other historical monuments in different periods. Her figurative sketch seems to have changed in a different way each time but it is always associated with a maternal function of birthing, protection and care. We can see that the table 
consists of one main cell and other cells correspondingly divided into two. The first column of the main cell shows the archaic, divine, and periodic characteristics of Mother Umai. There are figurative images of mother Umai at each stage in the second column of the main cell (Fig. 6). We have inferred the following interesting facts from the table. When we systematized the chronological expressions of goddess Umai, its missionary side was more strongly noticed. Throughout the IX-X centuries, the image of mother Umai on a stone (boulder stone or petroglyph) is often found in different locations close to the Altai [Chebodaeva, 2019,27]. In our opinion, at this time there were great changes in Central Asia, as the Islamic religion started to spread and flourish. Perhaps at that time, or even before the advent of Islam, the local aborigines also worshipped these stone boulders and petroglyphs. The geographer, scholar and historian AlBiruni, who lived during the spread of Islam in Central Asia, left historical information about the peoples who worship the image on the stone [Agapov, 1979, 73].

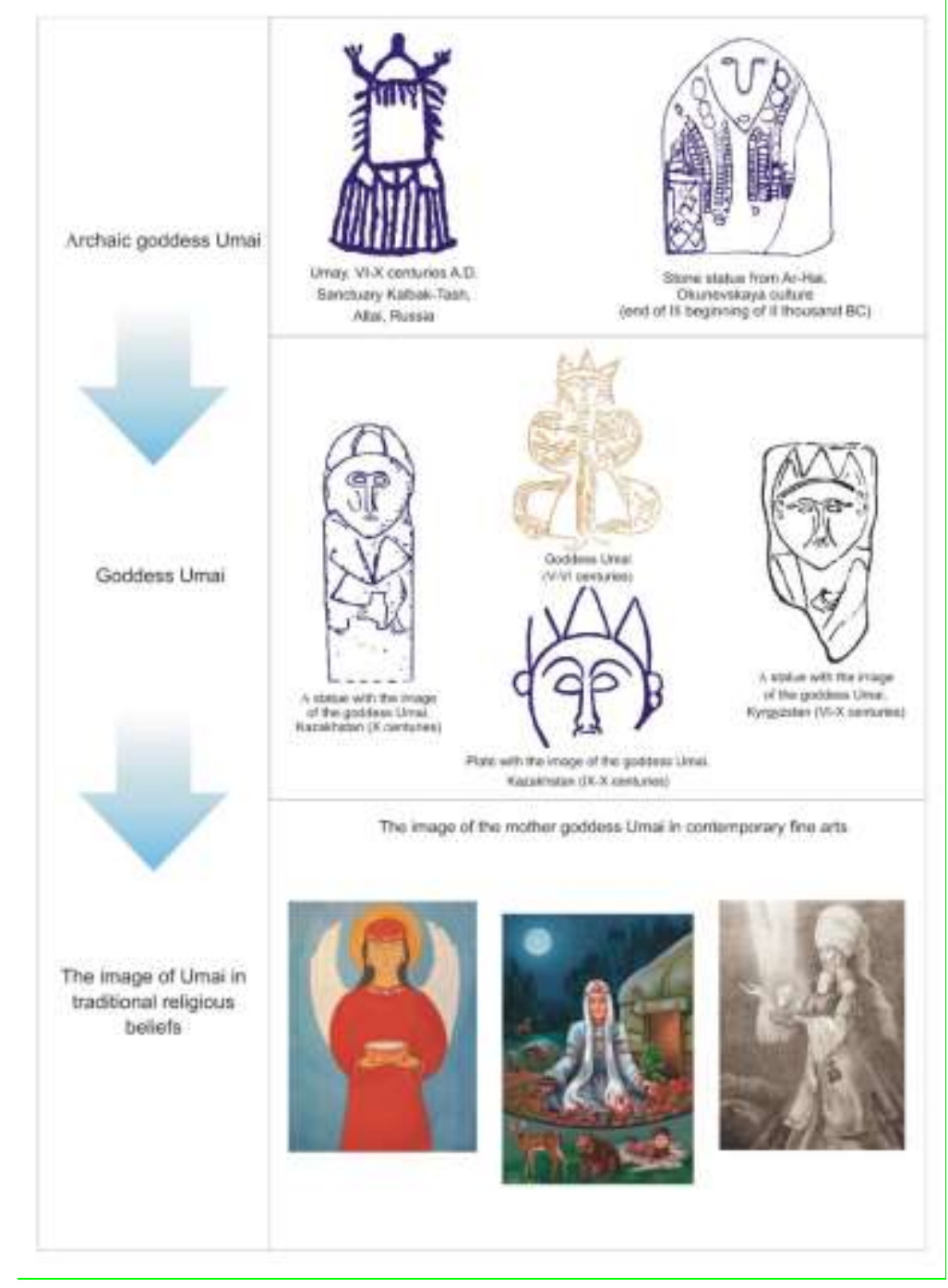

Figure 7: Icon image and religious forms

What is fundamental to an interpretation is thus the historical and archaeological role of the petroglyph for the Russian cultures of the Altai and the Tengrian religion of the mother. During 
the archaeological excavations and scientific research of grave No. 16, scholars analyzed the petroglyphic signs related to the "burial of the child" rites. The findings of the meaning related to the third part of the petroglyph may not be fully available, since the additional find in the grave was not specifically addressed. The main lead for us follows from semiotic analysis of the image in the petroglyph. The question whether the panel refers to a "sacrifice" has been examined. Acts of "sacrifice", including the sacrifice and burial of people according to an ancient archaic ritual rule, were widespread in archaeological excavations. For this reason, we examined whether the meaning of the petroglyphs have a connection with the evidences from Rudenko's early archaeological exhumation. According to scholars who were engaged in archaeological excavations at the burial ground No. 16, the signs of petroglyphs related to the ceremony of "burial of a child". Accordingly, the pictorial episodes of the petroglyph were given analytical significance and analyzed to learn whether they refer to the event of the "sacrifice" (Gavrilova 1965), based on the importance of archaeological research. We also finally consider the meaning of the sign "Trinity", which defines the symbol of the main character of the petroglyphs Umai Kudayan. We were interested in the question of whether the Turkish lexicographer Mahmud Kashgari associated the meaning "comrade" while defining the word "Umay". Neither is the word "placenta" in medicine associated with the symbol "troika" in Altai cultures. If we take into account that goddess Umai was included in the ancient Russian religion, then it must have been part of the Tengrian religion, which flourished within the Altai Mountains itself. Since the world religions predominate in Central Asia in history, the Tengri religion was ultimately prevented from spreading goddess Umai's image in the rest of Central Asia and thus it became difficult for ever to decipher its complete meaning.

\section{References}

Agapov, Pavel.V. Kadyrbaev, M.K. Treasures of ancient Kazakhstan.Monuments of material culture.// AlmaAta: Zhalyn. 1979.250.

Alekseev, Nikolay.A. 1984. Shamanism of the Turkic-speaking peoples of Siberia (Experience of areal comparative research) Novosibirsk: Science, Siberian Branch, - 233 p.

Azbelev, Pavel P. 2010. «Kudyrgin plot» // St. Petersburg: 60 p. ISBN 978-3-98709-277-4.

Bart, Roland. 2003. «Fashion System. Articles on the semiotics of culture» // trans. with fr., entry. Art. and comp. S.N. Zenkina. - M .: Publishing house them. Sabashnikovs. 512

Brown, Emma L. Dixon, Ronald A. and Jason W. Birkett. 2014. «The Discolouration of Human Teeth from Archaeological Contexts: Elemental Analysis of a Black Tooth from a Roman Cranium Recovered from the River Witham, Lincoln, UK» Journal of Anthropology, Article ID 859153, 7 pages. http://dx.doi.org/10.1155/2014/859153

Cotterell, Arthur and Rachel Storm.1999. «The Complete Encyclopedia of Mythology» New York: Lorenz Books. pp. 466, 481. ISBN 0-7548-0091-1. https://www.amazon.it/Ultimate-Encyclopedia-MythologyComprehensive-Classical/dp/0754800911

Chebodaeva Maina P, 2019. The image of the Goddess Umai (Ymai) in the fine and decorative arts of Khakassia. Abakan.40 p. 
Diosegi V. 1955. Headdresses of Nanai shamans // Neprajzi Muzeum Ertesitoje, XXXVII. Budapest, Edwards, Eric. 2013 "The Cult of the Mother Goddess- (3) Earth Mothers and Mother Goddesses" https://ericwedwards.wordpress.com/2013/07/17/the-cult-of-the-mother-goddess/

Eliade, Mircea. 2014. «Shamanism: archaic techniques of ecstasy» Moscow: ladomir, - 552 p.

Gavrilova, Antonina.A. 1965. «Kudyrge burial ground as a source on the history of the Altai tribes» //M.-L.: $145 \mathrm{p}$.

Harner, Michael. 2009. "The ecological basis of the sacrifice of the Aztecs" // October American Ethnologist 4 (1): 117 - 135 DOI: 10.1525 / ae.1977.4.1.02a00070

Kotov, Vyacheslav G. 2010. «The female deity Umai / Humai: comparative characteristics» // Bulletin of the Altai State University. - No. 4-2. - S. 111-114.

Krenke, Nikolay A. 2019. «Radiocarbon Chronology of the Fatyanovo Culture» Russian Archeology 2, 110 116, Founders: Institute of Archeology RAS, Russian Academy of Sciences (Moscow) ISSN: 0869-6063.

Khudyakov, Julius S. 2010. "About the depiction of the deities of the ancient Turkic pantheon on the monuments of art of nomads of South Siberia and Central Asia the era of the early Middle Ages» // Antiquities of Siberia and Central Asia. No. 3 (15). Gorno-Altaysk:, 93-103.

Kubarev, Gleb V. 2017. «Old Turkic Statues from Apshiyakta, Central Altai: On Female Representations in Turkic Monumental Art». Archaeology Ethnology and Anthropology of Eurasia 45(1): 93-103. DOI: 10.17746/1563-0110.2017.45.1.093-103.

Little, Ame. Elliott, Benjamin. Conneller, Chantal. Pomstra, Diederic. Evans, Adrian A. Fitton, Laura K. Holland, Andrew, Davis, Robert. Kershaw, Rachel. O'Connor, Sonia. O'Connor, Terry. Sparrow, Thomas. Wilson, Andrew S. Jordan, Peter. Collins, Matthew J. Colonese, Andre Carlo. Craig, Oliver E. Knight, Rebecca. Luquin, Alexander. Taylor, Barry and Nicky Milner. 2016. «Technological Analysis of the World's Earliest Shamanic Costume: A Multi-Scalar, Experimental Study of a Red Deer Headdress from the Early Holocene Site of Star Carr, North Yorkshire, UK» PLOS ONE | DOI: 10.1371 / journal. pone.0152136 April 13.https://www.ncbi.nlm.nih.gov/pmc/articles/PMC4830440/

Martel, Alvaro. 2020. Semiotics and Meaning of Rock Art // Encyclopedia of Global Archaeology (pp.18)Publisher: Springer. DOI:10.1007/978-3-319-51726-1_2831-1

Mahmoud Kashkari. Turkish dictionary / comp. A. K. Egeubay. - 2007. - 592 P.

Mykhailova, Nataliia and Alan P. Garfinkel. 2018. "Horned hunter - shaman, ancestor, and deity" // Origin of language and culture: ancient history of mankind, Vol. 5, № 1, pages 5-26.

Nazarov, Ivan N. 2016. "Reflection of ritual traditions of kumandins of the altai region in the modern holiday culture" Cultural heritage of Siberia Volume 2 No. 20, 109-115

Place, Robert Michael. 2008. «Shamanism» / Robert M. Place ; consulting editor, Rosemary Ellen Guiley. 1st ed. p. cm. - (Mysteries, legends, and unexplained phenomena) 120.

Reich, Ina and Emily Chalmin. 2008. «Synchrotron Radiation and Cultural Heritage: A Combined XANES / XRF Study at the Mn K-Edge of Blue, Gray, or Black Paleontological and Archaeological Bone Material» Journal of Analytical Atomic Spectrometry 23 (6), 799-806 24.

Rédei, Anna Cabak. Peter Skoglund \&Tomas Persson. 2018. Applying cartosemiotics to rock art: an example from Aspeberget, Sweden Social Semiotics Volume 29, 2019 - Issue 4 Pages 543-556 Download citation https://doi.org/10.1080/10350330.2018.1488338 
Renfrew, Colin. 2004. Towards a theory of material engagement. In Rethinking materiality: The engagement of mind with the material world, ed. E. De Marrais, C. Gosden, and C. Renfrew, 23-31. Cambridge: McDonald Institute

Retz K.I. 2004. Belt plates with a scene of hunting for a wild boar from the Siberian collection of Peter: the question of chronological and cultural attribution // Bosphorus phenomenon: problems chronology and dating of monuments. Materials of the international scientific conference. - Part 2. -St. Petersburg: From the State Hermitage Museum, P. 325-332.

Rudenko, Sergey I. and Alexey N. Glukhov. 1927. «Kudyrge burial ground in Altai» // Materials on ethnography. T. III. Issue 2. 37-52.

Stepanova, E.V. 2013. Saddles from the Third Pazyryk burial mound // Culture of steppe Eurasia and their interaction with ancient civilizations. - Book 2. - St. Petersburg: NIMK RAS, "Periphery", - S.446-454.

Toboev, Arjan I. 2018. Shamanism in the traditional Altai culture / A. I. Toboev. - Gorno-Altaisk, - 112 p.

Zabolotskaya, Paraskovia E. 2011."Shamanic masks of the peoples of Siberia" // Siberian Journal of Philology. No. 3. S. 24-35.

Zhernosenko, Irina A. 2016. «Features of the iconography of the goddess Umai in the sacred centers of Altai» //Yaroslavl Pedagogical Bulletin No. 1, 312-317 